\title{
Institut d'études archéologiques de la province du Shaanxi. Xi'an Beizhou An Jia Mu. Pékin, Wenwu chubanshe, 2003, 113 p. + 118 ill. [Tombe d'An Jia (Zhou du Nord, Xi'an)]
}

\section{Étienne de La Vaissière}

\section{(2) OpenEdition}

\section{Journals}

Édition électronique

URL : http://journals.openedition.org/abstractairanica/3135

DOI : 10.4000/abstractairanica.3135

ISSN : 1961-960X

Éditeur :

CNRS (UMR 7528 Mondes iraniens et indiens), Éditions de l'IFRI

Édition imprimée

Date de publication : 15 mai 2005

ISSN : 0240-8910

\section{Référence électronique}

Étienne de La Vaissière, «Institut d'études archéologiques de la province du Shaanxi. Xi'an Beizhou An Jia Mu. Pékin, Wenwu chubanshe, 2003, 113 p. + 118 ill. [Tombe d'An Jia (Zhou du Nord, Xi'an)] », Abstracta Iranica [En ligne], Volume 26 | 2005, document 74, mis en ligne le 08 décembre 2005, consulté le 25 septembre 2020. URL : http://journals.openedition.org/abstractairanica/3135; DOI : https://doi.org/10.4000/abstractairanica.3135

Ce document a été généré automatiquement le 25 septembre 2020.

Tous droits réservés 


\section{Institut d'études archéologiques de la province du Shaanxi. Xi'an Beizhou An Jia Mu. Pékin, Wenwu chubanshe, 2003, 113 p. + 118 ill. [Tombe d'An Jia (Zhou du Nord, Xi'an)]}

Étienne de La Vaissière

1 La présence des Iraniens d'Asie centrale en Chine intérieure durant le Haut Moyen-âge continue de susciter un grand intérêt en Chine. Plusieurs colloques et publications leur sont consacrés. Ce volume fort bien illustré de dessins grand format et de photographies couleur est la publication définitive de la fouille de la tombe d'un Sogdien vivant en Chine au $6^{\mathrm{e}} \mathrm{s}$. Cette découverte avait fait l'objet de publications préliminaires (voir Abs. Ir. 24, c.r. $n^{\circ} 38$ ). Volume en chinois avec bref résumé anglais.

\section{INDEX}

Thèmes : 3.1. Est de l'Iran

Keywords : sogdian, grave

Mots-clés : Tombe

nompropre Sogdiens, Chine, China 
AUTEURS

ÉTIENNE DE LA VAISSIÈRE

ENS - Paris 